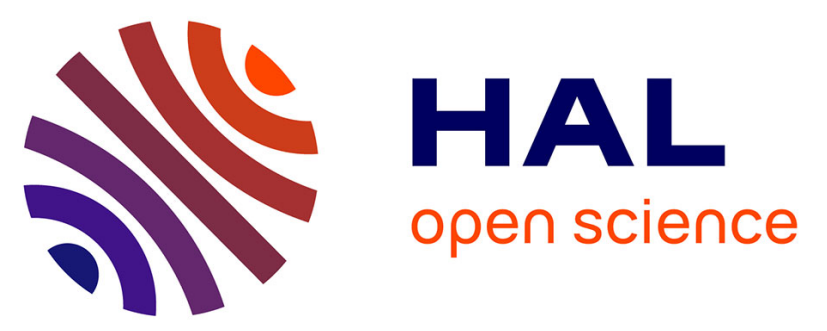

\title{
Knowledge, attitudes, behaviors, and practices differences regarding HIV in populations living along the Maroni river: particularities of operational interest for Amerindian and Maroon populations
}

Astrid van Melle, Marie-Claire Parriault, Célia Basurko, Anne Jolivet, Claude Flamand, Perrine Pigeon, Johanna Caudal, Nathalie Lydié, Sandrine Halfen, Marie-Thérèse Goerger-Sow, et al.

\section{- To cite this version:}

Astrid van Melle, Marie-Claire Parriault, Célia Basurko, Anne Jolivet, Claude Flamand, et al.. Knowledge, attitudes, behaviors, and practices differences regarding HIV in populations living along the Maroni river: particularities of operational interest for Amerindian and Maroon populations. AIDS Care, 2015, 27 (9), pp.1112-1117. 10.1080/09540121.2015.1032203 . hal-01260915

\section{HAL Id: hal-01260915 https://hal.science/hal-01260915}

Submitted on 22 Jan 2016

HAL is a multi-disciplinary open access archive for the deposit and dissemination of scientific research documents, whether they are published or not. The documents may come from teaching and research institutions in France or abroad, or from public or private research centers.
L'archive ouverte pluridisciplinaire HAL, est destinée au dépôt et à la diffusion de documents scientifiques de niveau recherche, publiés ou non, émanant des établissements d'enseignement et de recherche français ou étrangers, des laboratoires publics ou privés. 


\title{
Knowledge, attitudes, behaviors, and practices differences regarding HIV in populations living along the Maroni River: particularities of operational interest for Amerindian and Maroon populations
}

Astrid van Melle ${ }^{a}$, Marie-Claire Parriault ${ }^{a}$, Célia Basurko $^{a}$, Anne Jolivet $^{b}$, Claude Flamand $^{c}$, Perrine Pigeon $^{a}$, Johanna Caudal $^{\mathrm{a}}$, Nathalie Lydié ${ }^{\mathrm{d}}$, Sandrine Halfen ${ }^{\mathrm{e}}$, Marie-Thérèse Goerger-Sow ${ }^{f}$, Mathieu Nacher ${ }^{\mathrm{ag}}$

\author{
a Centre d'Investigation Clinique Antilles-Guyane, INSERM CIC 1424, Centre Hospitalier \\ Andrée Rosemon, Cayenne, France \\ b Centre Hospitalier Franck Joly, Saint Laurent du Maroni, France \\ c Institut Pasteur de la Guyane, Cayenne, France \\ d Institut National de prévention et d'éducation pour la santé, Paris, France \\ e Observatoire Régional de santé d'île de France, Paris, France \\ f Centre Hospitalier Universitaire de Pointe à Pitre, Pointe à pitre, France \\ g COREVIH Guyane, Centre Hospitalier Andrée Rosemon, Cayenne, France
}

\begin{abstract}
The Maroni basin, an isolated region delineating the border between Suriname and French Guiana has been affected by the human immunodeficiency virus (HIV) epidemic 10 years after coastal French Guiana. However, the rise in HIV prevalence was sharp, exceeding $1 \%$ within 10 years. The aim of the present study is to compare, using the first quantitative data from the general population in remote villages, the knowledge, attitudes, and behaviors regarding HIV between Maroon and Amerindian populations, the two most frequent populations living along the Maroni. Data were collected in 2012 using a structured questionnaire among a random sample of 896 individuals residing in the remote villages on the Maroni river. Proportions were compared between the Maroni and the coastal general population, and between Maroon and Amerindian populations. The present study shows significant differences between territories and between communities living on the Maroni river: the multiple sexual partnerships, more common among population living on the Maroni river, were more frequently reported in Maroons than in Amerindians. Condom use was more frequently reported among men on the Maroni river than on the coast, but these findings were reversed for women.

Moreover, among people living on the Maroni river, condom use was more frequently reported among Maroons than among Amerindians. Regarding genital factors that may affect transmission, penile implant seemed to have no ethnic boundaries, steam baths seemed specific to Maroon women. The present results should help to improve community-based specific interventions.
\end{abstract}

Keywords: Amerindian and descendants of Maroons populations; Maroni river; French Guiana; HIV; knowledge, attitudes, behaviors, practices. 


\section{Introduction}

The human immunodeficiency virus (HIV) epidemic on the Maroni river, marking the French Guiana-Suriname border, had an explosive spread with prevalence in pregnant women rising from 0 to $>1 \%$ within 10 years (Nacher et al., 2010; Tortevoye, Tuppin, Carles, Peneau, \& Gessain, 2005). Villagers are mainly Amerindians and Maroons. Whereas Maroon populations have been included in HIV programs, Amerindian populations from the upper Maroni have only been recently involved.

Although they are not yet affected by HIV, the continuity of territories where HIV prevalence exceeds $1 \%$, and the presence of most-at-risk populations could further spread the epidemic.

Despite the rapid progression of HIV along the Maroni, no quantitative behavioral data have ever been collected in the local population. A cross-sectional study was therefore conducted in 2012 to optimize and evaluate prevention.

The objective was to compare knowledge, attitudes, and behaviors regarding HIV between Amerindian and Maroon populations in order to adapt HIV prevention.

\section{Methods}

\section{Target population}

The study was conducted in 2012 over $250 \mathrm{~km}$ on the French side along the Maroni river. Amerindians, mostly Wayana, live mainly upstream from Maripasoula. Maroons (Aluku, Djuka, Paramaka, descendants of runaway slaves from the former Dutch colony), live between Maripasoula and Apatou. The target population included persons aged 18-69 years living in remote villages along the river (2009 census: $\mathrm{N}=11,909$ inhabitants).

\section{Sampling procedure}

A multistage stratified random sampling method was used. The number of persons to be surveyed $(\mathrm{N}=900)$ in each village was stratified proportionally to the local population size according to the 2008 census (National Institute for Statistic and Economics [INSEE]). Data were collected in all villages and in the largest kampus (temporary habitats related to itinerant agriculture (Jolivet, 2007), due to resource constraints. Households were selected exhaustively in the kampus and using a sampling scheme in village neighborhoods. A single eligible person was randomly selected in each household.

The questionnaire was derived from "Behavioral Surveillance Survey" questionnaires (Family Health International, 2000) and from the knowledge, attitudes, beliefs, and practices questionnaire (Halfen, Fenies, Ung, \& Gremy, 2006, Halfen, Lydié, Esvan, \& Diter, 2013).

Interviews were conducted by trained multilingual surveyors. The study received ethical approval (IRB00003888 No. 12-059).

\section{Variables}

Sociodemographic variables were recorded. Identification of the two populations relied on maternal language. Regular partners represent partners for over 6 months. Commercial partners were sex partners for money. Concurrent sexual partnerships were partnerships overlapping in time. Scales compiling responses to questions exploring stigma and discrimination, and transmission knowledge were created. An acceptance score was calculated for each participant as a proxy to tolerance toward people living with HIV (PLWHIV). It relied on answers to 4 questions and varied between 0 and 8 . No points were awarded for answers "no" and "no response", 1 point for "maybe" or "doesn't know" and 2 points for "yes". Similarly, knowledge about HIV-transmission corresponded to the number of correct answers to 7 items (for example, "Can you tell whether or not the AIDS 
virus can be transmitted by mosquito bite": "yes", "no", "doesn't know", "no answer"). The score ranged from 0 to 6,6 corresponding to better knowledge.

\section{Analysis}

Estimations were weighted to take into account the sampling scheme. A finite population correction was applied. A post-stratification adjustment, based on age and gender in each village was applied to each of these weights.

Proportions were compared between the Maroni sample and a random sample of 1586 persons aged 18-69 years living along the coast (Halfen et al., 2013). Since the age structure of the two populations was different, the analysis was restricted to those aged 18-44 years. Then, proportions were compared between Maroons and Amerindians. Variables with $p<0.05$ were fitted in a logistic model adjusting for six sociodemographic variables (gender, age, village/kampus, being born in France or not, schooled or not, and Maroon or Amerindian). Stata ${ }^{\circledR} 12.0$ (College Station, Texas) was used.

Results

Overall, 896 persons were interviewed (271 in Apatou, 150 in Grand Santi, 157 in Papaïchton, and 318 in Maripasoula), of which 382 men (43\%) and 514 women (57\%). The average age was 35 years. Nengue tongo was the maternal language for $3 / 4$ of the persons, $10.6 \%$ had an Amerindian maternal language. Table 1 describes population characteristics.

\section{Comparison between the Maroni and the coast}

Significant differences were observed (Table 2) between the general population of the isolated villages on the Maroni and those in the coastal area (where most people live): multiple sexual partnerships were more frequent in men residing along the Maroni. Men and women residing in the remote villages on the Maroni were more likely to declare having had an HIV test during their lifetime than those living in coastal areas. Women living along the Maroni were less likely to have used a condom during their lifetime. On the contrary, men along the Maroni were more likely to report having used a condom during their lifetime.

\section{Comparison between Amerindians and Maroons}

Table 3 shows no significant differences between the populations regarding first sexual intercourse, use of condoms with a regular partner, HIV-transmission knowledge, negative attitudes toward PLWHIV, HIV testing, or penile implants.

Univariate analysis showed significant differences between populations. After controlling for confounding, the Maroon-Amerindian variable was associated with having had more than one partner within the year, having used a condom, having had a casual partner within the year, and doing vaginal steam baths. Conversely, the variable Maroon-Amerindian was not associated with having had sex with sex worker within the year, and with feeling sufficiently informed on HIV.

\section{Discussion}

This study had possible limitations. Individual selection possibly excluded mobile at-risk persons (Gaubert-Maréchal et al., 2012). Some answers may have been biased toward socially desirable or non-embarrassing answers. Finally, the scores used were not formally validated.

Nevertheless, this is the first quantitative study in this unique setting affected by HIV.

The comparisons between the coast and the Maroni show behavioral differences requiring specific prevention interventions. The frequency of the multiple sexual partnerships reinforces the 
idea that this is an important driver of the epidemic on the Maroni (Nacher et al., 2010). Moreover, the connection between the general population and vulnerable groups may be bridged by mobile boatmen, with risky sexual behaviors, notably contacts with sex workers (Gaubert-Maréchal et al., 2012). The present study also suggests that paid-sex among men living on the Maroni is important. Illegal gold mining also frequently entails sex workers rotating on the mining sites (Parriault, 2012; Guillemaut \& Schutz Samson, 2011). Thus interventions should both target vulnerable groups, and the general population (Wilson \& Halperin, 2008).

For all populations, interventions should aim both at improving knowledge and changing behaviors, notably by attempting to modify cultural norms through local opinion leaders (Coates, Richter, \& Caceres, 2008; Wilson, 2004). Behavioral actions could focus on reducing multiple sexual partnerships, promoting condoms for casual sex and delaying first sex, and promoting HIV testing.

A number of bivariate differences between Maroons and Amerindians disappeared with multivariate analysis, thus showing sociodemographic confounding and/or reflecting insufficient sample size for Amerindians.

Thus, the only significant differences between Maroons and Amerindians concerned multiple sexual partnerships and condom use. The latter could be explained by the fact that Amerindian populations living before Maripasoula were not affected by HIV and had only been recently benefited from prevention interventions. Nevertheless, it seems important to improve condom use, notably among Amerindian women. Teaching interpersonal skills may help women to negotiate condom use (Albarracin et al., 2005). Improving condom availability may also contribute to condom use (Albarracin et al., 2005).

Dry sex refers to the use of plants to dry and contract the vagina (Gray \& Garcia, 2013; Halperin, 1999; Terborg \& Boven, 2000). This practice has been described in Aluku populations (Fleury, 1996) and Djuka (Vernon, 1992) in French Guiana. Afro-Surinamese women generally use genital steam baths with astringent herbs (van Andel, de Korte, Koopmans, Behari-Ramdas, \& Ruysschaert, 2008). This may damage vaginal tissues, change the bacterial flora and contribute to STDs (van Andel et al., 2008). Dry sex is also described as hampering condom use (Civic \& Wilson, 1996). Here, $95 \%$ of Maroon women declared doing astringent baths. This raises the question of the catalytic role of dry sex in the HIV epidemic.

Penile implants seem to have appeared on the Maroni during the civil war (Terborg \& Boven, 2000). Penile implants ("inert objects placed beneath the skin of the penis through an incision"), hamper condom use (breakage, incorrect fit; Yap et al., 2013). Here, 17\% of Maroons and $9 \%$ of Amerindians declared penile implants. Female condoms may thus be a more appropriate protection for these men.

Whereas this male cultural trend seemed to have no ethnic boundaries, steam baths seemed specific to Maroon women.

The HIV epidemic is still active in this region and prevention needs to be as good as it can get. The present study shows significant differences between communities. Whereas some of them are better explained by sociodemographic determinants others are clearly cultural. Suriname has identified Maroon and Amerindian populations in the interior as most-at-risk populations (Country Coordinating Mechanism Suriname, 2005). The present results should help to improve communitybased specific interventions on both sides of the border.

\section{Acknowledgement}

The study is part of the project "Mise en place d'un observatoire intercaribéen du VIH" supported by the University Hospital of Pointe-à-Pitre.

\section{Funding}

The present study was supported by the European INTERREG Caribbean IV Fund, by Hospital of Cayenne and by University Hospital of Pointe-à-Pitre. 


\section{References}

Albarracin, D., Gillette, J. C., Earl, A. N., Glasman, L. R., Durantini, M. R., \& Ho, M. H. (2005). A test of major assumptions about behavior change: $\mathrm{A}$ comprehensive look at the effects of passive and active HIV-prevention interventions since the beginning of the epidemic. Psychological Bulletin, 131, 856897. doi:10.1037/0033-2909.131.6.856

Civic, D., \& Wilson, D. (1996). Dry sex in Zimbabwe and implications for condom use. Social Science and Medicine, 42(1), 91-98. doi:10.1016/0277-9536(95)00081-X

Coates, T. J., Richter, L., \& Caceres, C. (2008). Behavioural strategies to reduce HIV transmission: How to make them work better. Lancet, 372, 669-684. doi:10.1016/S0140-6736(08)60886-7

Country Coordinating Mechanism Suriname. (2005). Reducing the spread impact of HIV/AIDS in Suriname through expansion of prevention and support programs (Global Fund - Fifth round proposal). Paramaribo: Author. Document Number.

Family Health International. (2000). Behavioral surveillance survey: Guidelines for repeated behavioral surveys in populations at risk of HIV. Arlington, VA: Author. Document Number.

Fleury, M. (1996). Végétaux utilisés pour l'hygiène intime des femmes Aluku en Guyane française: interprétation culturelle et intérêt pharmacologique [Plants used for intimate hygiene of women Aluku in French Guiana: Cultural interpretation and pharmacological interest]. In E. Schröder, G. Balansard, P. Cabalion, J. Fleurentin, \& G. Mazars (Eds.), Médicaments et aliments : approche ethnopharmacologique [Medicines and foods : Ethnopharmacological approach] (pp. 178-186). Metz: ORSTOM.

Gaubert-Maréchal, E., Jolivet, A., Van-Melle, A., Parriault, M-C., Basurko, C., Adenis, A., ... Nacher, M. (2012). Knowledge, attitudes, beliefs and practices on HIV/AIDS among boatmen on the Maroni river: A neglected bridging group? Journal of AIDS \& Clinical Research, 3, 181. doi:10.4172/21556113.1000181

Gray, P. B., \& Garcia, J. R. (2013). Evolution and human sexual behavior. Cambridge, MA: Harvard University Press.

Guillemaut, F., \& Schutz Samson, M. (2011). Travail du sexe et mobilité en Guyane, des défis pour la lutte contre le $\mathrm{VIH} /$ sida [Sex work and mobility in french Guiana, challenges for the fight against HIV/AIDS]: Ministère du Travail, de l'Emploi et de la Santé, Direction Générale de la Santé -DGS/RI 2, Bureau des infections par le VIH, les IST et les hépatites. Document Number.

Halfen, S., Fenies, K., Ung, B., \& Gremy, I. (2006). Les connaissances, attitudes, croyances et comportements face au VIH/sida aux Antilles et en Guyane en 2004 [Knowledge, attitudes, beliefs and behaviours towards HIV/AIDS in French West Indies and Guiana in 2004]. Paris: Agence nationale de recherches sur le sida et les hépatites virales, Observatoire régional de santé d'Ile-de-France.

Document Number.

Halfen, S., Lydié, N., Esvan, M., \& Diter, K. (2013). Connaissances, opinions et utilisation des préservatifs dans la population générale adulte de Guadeloupe, Martinique et Guyane: évolutions 2004-2011 [Knowledge, opinions and condom use in the adult general population in Guadeloupe, Martinique and Guiana (France): Trends for 2004-2011]. Bulletin Epidémiologique Hebdomadaire, 39-40, 496-503. 
Halperin, D. T. (1999). Dry sex practices and HIV infection in the Dominican Republic and Haiti. Sexually Transmitted Infections, 75, 445-446. doi:10.1136/sti.75.6.445

Jolivet, M.-J., \& Vernon, D. (2007). Droits, polygamie et rapports de genre en Guyane [Rights, polygamy and gender relations in French Guiana]. Cahiers d'études africaines, 47(Numéro 187-188), 733-752.

Nacher, M., Vantilcke, V., Parriault, M. C., Van Melle, A., Hanf, M., Labadie, G., ... Couppié, P. (2010). What is driving the HIV epidemic in French Guiana? International Journal of STD and AIDS, 21, 359361. doi:10.1258/ijsa.2010.009570

Parriault, M. C. (2012). Les connaissances, attitudes et pratiques vis-à-vis du VIH et des IST parmi les travailleurs du sexe en Guyane [Knowledge, attitudes and practices toward HIV and STIs among female sex workers in French Guiana] (2009-2010). Cayenne: CIC Antilles-Guyane. Document Number.

Terborg, J., \& Boven, K. (2000). Sexual behavior and sexually transmitted diseases among maroon and indigenous populations in the hinterland of Suriname. Paramaribo: Medical Mission. (ProHealth, Primary, Health, Care, Suriname).

Tortevoye, P., Tuppin, P., Carles, G., Peneau, C., \& Gessain, A. (2005). Comparative trends of seroprevalence and seroincidence rates of human $T$ cell lymphotropic virus type I and human immunodeficiency virus 1 in pregnant women of various ethnic groups sharing the same environment in French Guiana. The American Journal of Tropical Medicine and Hygiene, 73, 560-565.

van Andel, T., de Korte, S., Koopmans, D., Behari-Ramdas, J., \& Ruysschaert, S. (2008). Dry sex in Suriname. Journal of Ethnopharmacology, 116(1), 84-88. doi:10.1016/j.jep.2007.11.003

Vernon, D. (1992). Les représentations du corps chez les noirs marrons njuka du Surinam et de la Guyane française [Representations of the body among maroons njuka from Suriname and French Guiana]. Paris: Institut français de recherche scientifique pour le développement en cooperation.

Wilson, D. (2004). Partner reduction and the prevention of HIV/AIDS. BMJ, 328, 848-849. doi:10.1136/bmj.328.7444.848

Wilson, D., \& Halperin, D. T. (2008). "Know your epidemic, know your response": A useful approach, if we get it right. Lancet, 372, 423-426. doi:10.1016/S0140-6736(08) 60883-1

Yap, L., Butler, T., Richters, J., Malacova, E., Wand, H., Smith, A. M., ... Donovan, B. (2013). Penile implants among prisoners-A cause for concern? PLoS One, 8, e53065. doi:10.1371/journal.pone.0053065.t001 


\begin{tabular}{|c|c|c|c|}
\hline Variable & $\begin{array}{c}\text { Maroons (N=677) } \\
\%\end{array}$ & $\begin{array}{c}\text { Amerindians ( } \mathrm{N}=91) \\
\%\end{array}$ & $p^{*}$ \\
\hline \multicolumn{4}{|l|}{ Gender (N=768) } \\
\hline Male & 41,8 & 41,8 & \multirow{2}{*}{0,99} \\
\hline Female & 58,2 & 58,2 & \\
\hline Mean age $(\mathrm{N}=768)$ & 35,7 & 34,8 & $0,48^{\star \star}$ \\
\hline \multicolumn{4}{|l|}{ Living in a village or in a kampu ( $N=768)$} \\
\hline Proper village & 58,6 & 8,8 & \multirow{2}{*}{$<0,0001$} \\
\hline Kampu & 41,4 & 91,2 & \\
\hline \multicolumn{4}{|l|}{ Reading french $(\mathrm{N}=764)$} \\
\hline Not at all & 43,4 & 36,2 & \multirow{4}{*}{0,10} \\
\hline Yes, with a lot of difficulties & 14,1 & 17,6 & \\
\hline Yes, with few difficulties & 12,6 & 20,9 & \\
\hline Yes, without difficulties & 29,9 & 25,3 & \\
\hline \multicolumn{4}{|l|}{ Having gone to school $(\mathrm{N}=768)$} \\
\hline 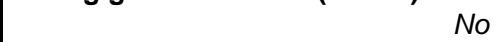 & 27,5 & 28,6 & \multirow{2}{*}{0,83} \\
\hline Yes & 72,5 & 71,4 & \\
\hline \multicolumn{4}{|l|}{ Schooling final age $(\mathrm{N}=555)$} \\
\hline Before 16 years & 34,3 & 46,2 & \multirow{3}{*}{0,16} \\
\hline Between 16 and 20 years & 47,1 & 36,9 & \\
\hline After 20 years & 18,6 & 16,9 & \\
\hline \multicolumn{4}{|l|}{ Having water in one's home $(\mathrm{N}=768)$} \\
\hline No & 45,6 & 92,3 & \multirow{2}{*}{$<0,0001$} \\
\hline Yes & 54,4 & 7,7 & \\
\hline \multicolumn{4}{|l|}{ Having electricity in one's home ( $N=762)$} \\
\hline No & 17,6 & 34,0 & \multirow{3}{*}{$<0,0001$} \\
\hline Yes, by national electricity board & 67,4 & 17,6 & \\
\hline Oui by private generator & 15,0 & 48,4 & \\
\hline \multicolumn{4}{|l|}{ Professional Status ( $N=768)$} \\
\hline Doesn't work & 41,7 & 60,4 & \multirow{5}{*}{$<0,0001$} \\
\hline Permanent contract & 8,4 & 6,6 & \\
\hline Fixed-term contract & 10,6 & 9,9 & \\
\hline Yes without contract & 35,3 & 9,9 & \\
\hline Independant & 4,0 & 13,2 & \\
\hline \multicolumn{4}{|l|}{ Nationality $(\mathrm{N}=767)$} \\
\hline French & 59,0 & 81,3 & \\
\hline Surinamease & 39,8 & 16,5 & $<0,0001$ \\
\hline Other & 1,2 & 2,2 & \\
\hline Having french health insurance $(\mathrm{N}=7$ & & & \\
\hline No & 28,6 & 18,7 & 0.05 \\
\hline Yes & 71,4 & 81,3 & 0,05 \\
\hline Having a surinamese health insuranc & $(\mathrm{N}=764)$ & & \\
\hline No & 86,3 & 95,6 & \\
\hline Yes, $M Z$ & 12,3 & 1,1 & 0,003 \\
\hline Yes RGD & 1,3 & 3,3 & \\
\hline Using traditional medicine $(\mathrm{N}=766)$ & & & \\
\hline No & 56,3 & 62,6 & \\
\hline Yes & 43,7 & 37,4 & 0,25 \\
\hline Importance of religion $(\mathrm{N}=750)$ & & & \\
\hline It is very important & 31,9 & 42,9 & \\
\hline It is important or very important & 44,8 & 39,5 & 0,10 \\
\hline it is not important & 23,4 & 17,6 & \\
\hline In relationship $(\mathrm{N}=768)$ & & & \\
\hline No & 32,2 & 25,3 & 018 \\
\hline Yes & 67,8 & 74,7 & 0,18 \\
\hline Drinking more than 5 drinks in 4 hou & rs in the past 4 we & eks ( $N=319)$ (Male) & \\
\hline No & 63,7 & 55,3 & 001 \\
\hline Yes & 36,3 & 44,7 & 0,31 \\
\hline Drinking more than 5 drinks in 4 hou & rs in the past 4 wee & eks $(N=446)$ (Female) & \\
\hline No & 87,8 & 86,8 & \\
\hline Yes & 12,2 & 13,2 & 0,84 \\
\hline $\begin{array}{l}{ }^{*} \text { Chi }{ }^{2} \text { test } \\
{ }^{* *} \text { ttest }\end{array}$ & & & \\
\hline
\end{tabular}

Table 1 : Comparison of characteristics between Maroons and Amerindian living in the remote villages on maroni river 


\begin{tabular}{|c|c|c|c|c|c|}
\hline \multirow{2}{*}{ Variable } & \multirow{2}{*}{\multicolumn{2}{|c|}{$\begin{array}{c}\text { Coastal French } \\
\text { Guiana }\end{array}$}} & \multirow{2}{*}{\multicolumn{2}{|c|}{$\begin{array}{c}\text { Maroni } \\
\text { 18-44 years }\end{array}$}} & \multirow{2}{*}{$p^{*}$} \\
\hline & & & & & \\
\hline \multicolumn{6}{|c|}{ Sexual History } \\
\hline Having had more than one partner in the past 12 months (Male) & 32,25 & 377 & 49,37 & 277 & $<0,001$ \\
\hline Having had used a condom in one's life (Male) & 94,66 & 409 & 97,50 & 292 & 0,03 \\
\hline Having had used a condom in one's life (Female) & 91,56 & 614 & 84,48 & 412 & $<0,001$ \\
\hline \multicolumn{6}{|c|}{ HIV test } \\
\hline Having had an HIV test in one's life (Male) & 68,15 & 423 & 88,63 & 291 & $<0,001$ \\
\hline Having had an HIV test in one's life (Female) & 87,86 & 631 & 93,22 & 409 & 0,003 \\
\hline
\end{tabular}

Table 2 : Comparison of behavioral standard between coastal population (KABP-ORS Guiana 2011 study) and population living in the remote villages on maroni (CAP Maroni study)

\begin{tabular}{|c|c|c|c|c|}
\hline Variable & Maroons \% & Amerindians \% & $p^{*}$ & Adj. odds ratios (95.Cl)\# \\
\hline First sexual intercourse & $\mathrm{N}=673$ & $\mathrm{~N}=91$ & & \\
\hline Having had first sexual intercourse before 15 years (male) & 54,4 & 33,5 & 0,09 & - \\
\hline Having had first sexual intercourse before 15 years (female) & 36,5 & 49,7 & 0,14 & - \\
\hline \multicolumn{5}{|l|}{ The first sexual intercourse was } \\
\hline Wished (male) & 93,8 & 100,0 & \multirow{3}{*}{0,36} & - \\
\hline Accepted but not wished (male) & 5,5 & 0,0 & & - \\
\hline Forced (male) & 0,7 & 0,0 & & - \\
\hline Wished (female) & 80,3 & 82,6 & \multirow{3}{*}{0,47} & - \\
\hline Accepted but not wished (female) & 13,2 & 6,0 & & - \\
\hline Forced (female) & 6,6 & 11,4 & & - \\
\hline Sexual history (in the past 12 months) & $\mathrm{N}=579$ & $\mathrm{~N}=71$ & & \\
\hline Having had more than one partner (male) & 50,5 & 6,7 & $<0,001$ & \multirow{2}{*}{$0,10(0,03-0,29)$} \\
\hline Having had more than one partner (female) & 3,0 & 1,0 & 0,14 & \\
\hline Having had a sex worker partner (male) & 6,1 & 0,6 & 0,006 & $0,52(0,08-3,19)$ \\
\hline Having had casual partner(s) (male) & 48,2 & 6,7 & $<0,001$ & \multirow{2}{*}{$0,09(0,03-0,27)$} \\
\hline Having had casual partner(s) (female) & 6,6 & 0,0 & 0,16 & \\
\hline Condoms use in one's life & $\mathrm{N}=670$ & $\mathrm{~N}=91$ & & \\
\hline Having had used a condom in one's life (male) & 95,9 & 85,8 & 0,01 & \multirow{2}{*}{$0,31(0,13-0,73)$} \\
\hline Having had used a condom in one's life (female) & 73,4 & 53,7 & 0,02 & \\
\hline Condom use with regular partner & $\mathrm{N}=512$ & $\mathrm{~N}=71$ & & \\
\hline Having used a condom for the last intercourse & 27,47 & 22,50 & 0,48 & - \\
\hline Negative attitudes towards people living with HIV & $\mathrm{N}=667$ & $\mathrm{~N}=73$ & & \\
\hline Mean score & $3,18(2,89-3,47)$ & $2,98(1,96-3,96)$ & $0,69^{\star \star}$ & - \\
\hline Knowledge & $\mathrm{N}=667$ & $\mathrm{~N}=73$ & & \\
\hline Mean score level of knowledge of HIV transmission & $4,5(4,35-4,61)$ & $4(3,44-4,56)$ & $0,10^{\star *}$ & - \\
\hline HIV test & $\mathrm{N}=667$ & $\mathrm{~N}=73$ & & \\
\hline Having had an HIV test (male) & 88,2 & 84,4 & 0,54 & - \\
\hline Having had an HIV test (female) & 92,8 & 86,2 & 0,27 & - \\
\hline Being favorable to rapid HIV test & 92,7 & 93,1 & 0,92 & - \\
\hline Prevention & $\mathrm{N}=665$ & $\mathrm{~N}=73$ & & \\
\hline Have heard prevention messages & 97,9 & 95,3 & 0,18 & - \\
\hline Feeling sufficiently informed about HIV & 25,2 & 9,8 & 0,01 & $0,48(0,18-1,28)$ \\
\hline \multicolumn{5}{|l|}{ Specific pratices } \\
\hline Having penil implants $(\mathrm{N}=316)$ & 16,6 & 9,3 & 0,31 & \\
\hline Doing genital steam baths (female) $(\mathrm{N}=444)$ & 96,1 & 4,2 & $<0,001$ & $0,0004(0,00004-0,005)$ \\
\hline \multicolumn{5}{|c|}{$\begin{array}{l}{ }^{*} \text { Chi }{ }^{2} \text { test }{ }^{* *} \text { Wald test } \\
\# \text { OR being amerindian vs maroon populations } \\
{ }^{* *} \text { Each significant variable }(p<0,05) \text { has been included in a multivariate model and adjusted on } 6 \text { sociodemographic variables (gender, age, living in a proper } \\
\text { village or kampu (which indicate remoteness), being born in France/or foreign-born, having gone to school or not and being Maroons or Amerindians). }\end{array}$} \\
\hline
\end{tabular}

Table 3 : Comparison of behavioral standard between maroon and amerindian populations living in the remote villages on the maroni river 